\title{
Museums as weavers of the invisible strings that connect us
}

\author{
Sara Konrath ${ }^{1,2,3}$ \\ 1. Associate Professor, Lilly Family School of Philanthropy, Indiana University, Indianapolis, IN \\ 2. Affiliate Faculty, Institute for Social Research, University of Michigan, Ann Arbor, MI \\ 3. Visiting Scholar, Psychology Department, New School for Social Research, New York, NY
}

\begin{abstract}
Author note: A version of this essay was presented at the Association for Art Museum Directors conference in Minneapolis, MN in May 2018. I am grateful to members of the Empathy and Visual Arts Think Tank, organized by Kaywin Feldman and Karleen Gardner of the Minneapolis Institute of Art in October 2017, for deep discussions and questions that inspired this research project. The other attendees are listed here in alphabetical order: Alex Bortolot, Paul Gabriel, Elif Gokcigdem, Marco Iacoboni, Dacher Keltner, Danielle Krettek, Timothy Patrick McCarthy, Dana Mekler, Elise Ogle, Dario Robleto, Emiliana Simon-Thomas, and Natalie Wright. Thanks to Ryan Bremner for feedback on an early version of the paper. I am also grateful to the Corporation for National and Community Service (current funding) and the John Templeton Foundation (past funding).
\end{abstract}

This is the author's manuscript of the article published in final edited form as:

Konrath, S. (2019). Museums as Weavers of the Invisible Strings that Connect us. Journal of the Australian Library and Information Association, 68(4), 327-342. https://doi.org/10.1080/24750158.2019.1670772 


\begin{abstract}
:
This paper reviews the quantitative research literature on changes over time in social connection and self-focus in the United States. It discusses the implications of these changes for the need for meaning, and in terms of mental health trends in the US. It then suggests that art museums can play a critical role in helping communities re-connect, by reenvisioning their roles as meaning makers in a society when people's existential needs are threatened. It ends by providing specific suggestions that art museums can try to re-connect people in their communities.
\end{abstract}

Key words: temporal trends; empathy; trust; narcissism; individualism; meaning; art museums; social and emotional needs; evidence-based practices 
When my son was five, during a bedtime chat, he told me that he is not worried about getting lost at a fair or anywhere, because he sees the invisible strings that connect us. He said that he sees the strings connecting him to his family members and everyone he knows, and that means that no matter where we are, he is not alone. His metaphor is an apt description of the interconnectedness of social life (Watts, 2004). This paper will present evidence that social connections are declining in the United States in recent years. And I will suggest that art museums can do something about this that will also help them to be more sustainable.

\section{The decline of connection}

Research is finding declines in social interest and closeness in recent generations of Americans. For example, between 1979 to 2009, American college students declined in trait empathy (Konrath, O'Brien, \& Hsing, 2011), which is defined as imagining others' perspectives and feeling care and compassion for them. There are similar results in nationally representative samples of American high school students (Twenge, Campbell, \& Freeman, 2012).

If one is skeptical of changes in self-reported traits and beliefs, behaviorally, these translated into declines in charitable donations (Rooney, Wang, \& Ottoni-Wilhelm, 2018; Twenge, Campbell, \& Freeman, 2012) and helping behaviors over time (Hampton, 2016; Levine, Reysen, \& Ganz, 2008). Although there has been an overall decline in the rate of volunteering among Americans since 2005 (Dietz \& Grimm, 2016), there are generational changes that go in the opposite direction: Millennials are actually more likely to volunteer than previous generations (Twenge, Campbell, \& Freeman, 2012). Yet, this is likely explained by an increase in mandatory volunteer programs in high schools and the importance of volunteering for college admissions - meaning that the "volunteering" isn't exactly voluntary. For example, in 1984, less than $4 \%$ of public high schools required community service to graduate, but this rose to $37 \%$ by 2008 (Spring, Grimm, \& Dietz, 2008).

This decline in a focus on others is also evident in American cultural products such as books, song lyrics, and political speeches, which have been using fewer other-oriented words and phrases over time, across longer historical periods (Chopik, Joshi, \& Konrath, 2014; DeWall, Pond, Campbell, \& Twenge, 2011; Greenfield, 2013; Grossmann \& Varnum, 2015; Kesebir \& Kesebir, 2012; Konrath \& Anderson, 2011; Twenge, Campbell, \& Gentile, 2012, 2013).

At the same time, cynicism is increasing over time among Americans, who are less likely to believe that others are good and trustworthy (Hochreich \& Rotter, 1970; Rahn \& Transue, 1998; Schwadel \& Stout, 2012; Twenge, Campbell, \& Carter, 2014; Twenge, Campbell, \& Freeman, 2012). Trust is the foundation for all relationships - it allows us to believe the best in others, whether these are our friends, romantic partners, business associates, or politicians.

Our social worlds are shrinking. Family sizes have been declining over time (Bureau, 2017a, 2017b), and there has been an increase in the percentage of Americans who live alone, nearly doubling from 7.6 percent in 1967 to 14.3 percent in 2017 (Bureau, 2017c; Wilson, 2017). There has also been a decrease in the number of confidantes that people report having, with $10 \%$ of Americans saying that had no one to talk to about important matters in 1985, which rose to 24.6\% in 2004 (McPherson, Smith-Lovin, \& Brashears, 2006).

Finally, there have been declines in religious participation over time, with the percent of Americans who have no religious affiliation quadrupling from the 1970 s to 2010 s (5\% to $20 \%$; (GSS, 2016c). Regardless of one's personal beliefs when it comes to religion, religious participation is an important source of social connections for people.

\section{The rise of control}


Connection is about genuine closeness and compassion with others, but control is about seeking power, status, fame, personal achievement, and material possessions. Connection and control tend to be in tension with each other. Research finds that it is very difficult to be high in both - typically, people who are high on one are low on the other (Konrath, Meier, \& Bushman, 2014; Watson \& Morris, 1991). Connection is associated with more positive outcomes, such as better relationships, well-being, and physical health - even a longer lifespan, with generally opposite results for control (Carmichael, Reis, \& Duberstein, 2015; Holt-Lunstad, Smith, Baker, Harris, \& Stephenson, 2015; Holt-Lunstad, Smith, \& Layton, 2010; Konrath \& Bonadonna, 2014).

So what is happening to control-related outcomes over time? Research has found that self-esteem has been increasing over time among American children and college students, especially after the 1980s (Gentile, Twenge, \& Campbell, 2010; Twenge \& Campbell, 2001). In itself, this would not necessarily be a problem, but what is happening to narcissism, which is an exaggerated and toxic form of self-esteem? Several studies have tracked narcissism from the 1980 s to 2009, and found an increase in this trait over time among college students (Twenge \& Foster, 2010; Twenge, Konrath, Foster, Campbell, \& Bushman, 2008). In addition, between 1960 and 2011, an increasing percentage of Americans endorsed individualistic values such as independence and self-expression (Santos, Varnum, \& Grossmann, 2017).

Amidst rising rates of economic inequality between the 1970s and 2000s (Piketty, 2014), there was a corresponding rise in beliefs that everyone gets what they deserve and deserves what they get (Malahy, Rubinlicht, \& Kaiser, 2009). There was also a rise in materialistic values: the percent of incoming American college students who reported that being very well off financially was an essential or very important life goal doubled from $42 \%$ in 1967 to $82 \%$ in 2015 (Eagan et al., 2016). At the same time, there was nearly a reversal in the percent of students who reported that it was important to develop a meaningful philosophy of life, with $86 \%$ of students prioritizing meaning in 1967 , and only $47 \%$ doing so by 2015 . Across the same time period, students said that they wanted more leisure time, money, and status in their future jobs (Twenge, Campbell, Hoffman, \& Lance, 2010), but were less willing to work hard to achieve their goals (Twenge \& Kasser, 2013). This signals an increasing sense of entitlement. Especially concerning is the increase in perfectionism that occurred between 1989 and 2016 in college students (Curran \& Hill, 2019).

A rise in indicators of individualistic self-focus is also evident in American cultural products such as books, song lyrics, and political speeches, which have included more selforiented words and phrases over time, across longer historical periods (Chopik et al., 2014; DeWall et al., 2011; Greenfield, 2013; Grossmann \& Varnum, 2015; Kesebir \& Kesebir, 2012; Konrath \& Anderson, 2011; Twenge, Abebe, \& Campbell, 2010; Twenge, Campbell, \& Gentile, 2012; Twenge et al., 2013; Twenge, VanLandingham, \& Keith Campbell, 2017).

\section{An existential crisis: The misery of an atomized self}

The declines in connection and rise of control suggest a fraying and snapping of the invisible strings that connect us. These changes have deep implications for younger people's ability to engage in and prioritize close committed relationships, and declines in general trust suggest that these problems extend to their broader social and community networks. Ultimately, all of these changes point to an existential crisis among American young adults. This is likely to have mental health implications, since research finds that intrinsic goals (e.g. connections with others, personal growth) are associated with higher well-being and extrinsic goals (e.g. wealth, 
fame, success) are associated with lower well-being (Kasser \& Ryan, 1996; Ryan, Huta, \& Deci, 2008).

With declines in important sources of meaning over time, it is perhaps not surprising to see that there have indeed been parallel rises over time in mental illnesses such as depression and anxiety (Mojtabai \& Olfson, 2014; Olfson, Blanco, Wang, Laje, \& Correll, 2014; Twenge, 2015; $\mathrm{J}$ Twenge et al., 2010), and increasing rates of deaths of despair such as suicide and opioid overdoses (Control, 2016; Seth, Rudd, Noonan, \& Haegerich, 2018; Tavernise, 2016).

\section{What does this have to do with art museums?}

As Kurt Vonnegut wrote in his last published work, art is another critical source of meaning for people. "The arts are not a way to make a living. They are a very human way of making life more bearable. Practicing an art, no matter how well or badly, is a way to make your soul grow" (Vonnegut, 2005). I will next share some statistics on changes over time in arts participation, and how they align with broader social trends in the United States.

Declines in art museum attendance since the 1990s. According to two large nationally representative surveys (see Figure 1), there have been declines in the percent of Americans who reported attending art museums since the early 1990s, after a brief increase in the mid-1980s (GSS, 2016a; NEA, 2013; Roose \& Daenekindt, 2015).

Art museum memberships also declined from $26 \%$ in 2011 to $22 \%$ in $2017 .{ }^{1}$ There are many reasons for such declines (DiMaggio \& Mukhtar, 2004), but they are less surprising when situated within the context of broader declines in social connection and the rise of individualistic indicators.

Figure 1. Percentage of Americans who reported visiting an art museum in the past year

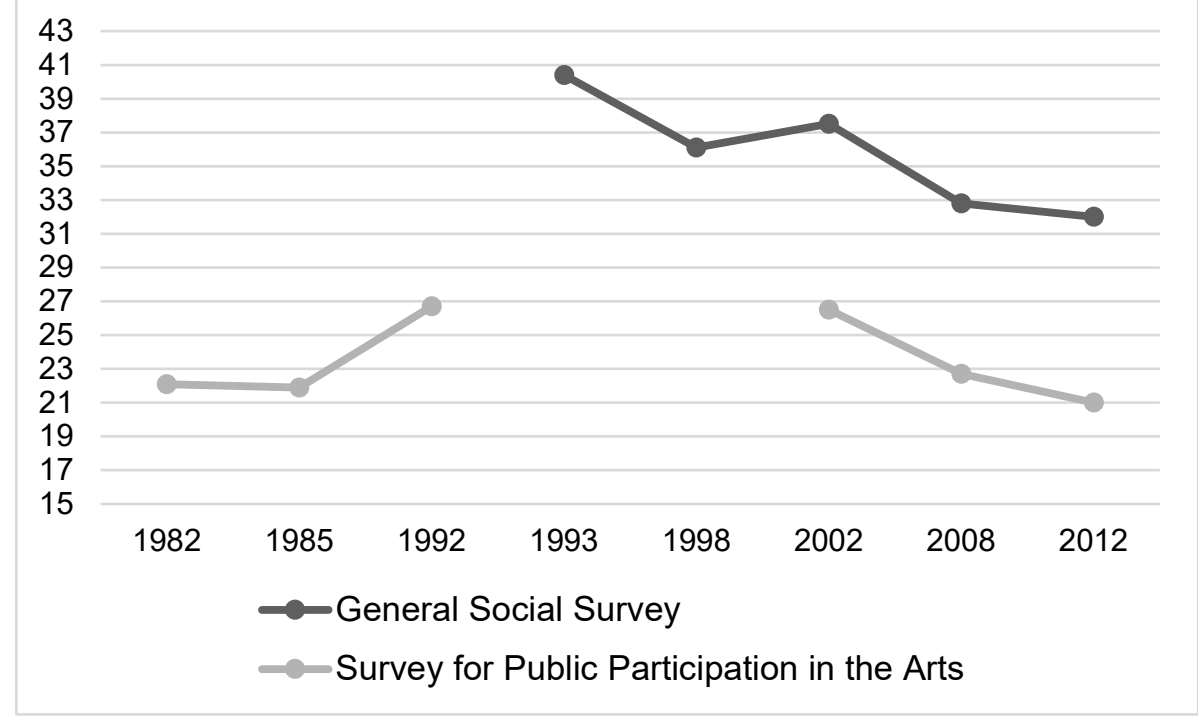

Increases in interest in creating visual art since the 1990s. Of course, there are many informal ways that people can participate in the arts, whether individually or socially. Just because formal participation is declining, does not mean that informal participation is declining. The rise of technology suggests that there is likely increased arts engagement over time via online sources (Stallings \& Mauldin, 2016). 
But other data suggests an increasing interest in informal visual arts participation. My analysis of General Social Survey data finds that $39.8 \%$ of Americans reported that they made an art or craft object in 1993, which after a slight dip to $37.8 \%$ in 1998 , moved up to $43.9 \%$ in 2002 (GSS, 2016b). I also analyzed data from The American Freshman Survey, which has tracked incoming college students since the mid-1960s. As can be seen in Figure 2, the percent of incoming college students who report that making art is an essential or very important life goal shows nearly the opposite trend as in art museum attendance, with a decline until the early 1990s and a rise in interest since then (Eagan et al., 2016).

Figure 2. Percent of American college freshman who said that creating artistic work (painting, sculpture, etc) was an essential or very important life goal

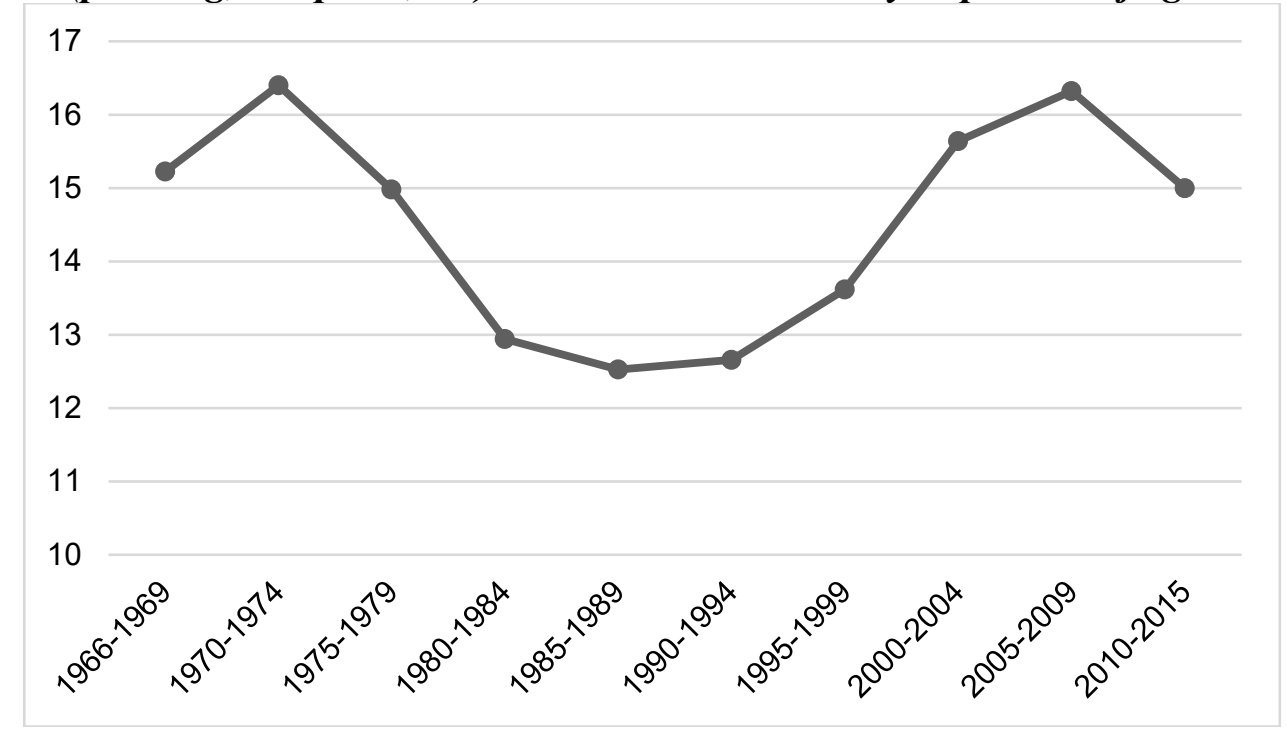

These more informal ways of participating in the arts align with the rise in individualistic cocooning seen in other domains, as reviewed above. The disjunction between what is happening inside versus outside of art museums represents an opportunity for them to capitalize on potentially increased interest in visual arts in more informal ways.

Declines in creative thinking over time. Other research has tracked change in objectively-assessed creative thinking styles over time. One of the most widely used tests of creative thinking is The Torrance Test of Creative Thinking (TTCT), which was developed in 1966. As an example, the figural version of the test asks people to create a picture using a pear or jellybean shape provided on the page. ${ }^{2}$ There are several different ways to score this test. Fluency is a count of the number of ideas that are listed in the time given. Originality is the number of responses that are seen rarely, less than $5 \%$ of the time. Elaboration includes the level of detail and complexity of the responses. Creative strengths are ratings of features of the figures, including emotional expressiveness, movement or action, expressiveness of titles, synthesis of incomplete figures, humor, richness of imagery, and fantasy. The TTCT is meaningfully connected to real world outcomes. For example, higher scores on it predict more creative achievement in people up to 50 years later (Runco, Millar, Acar, \& Cramond, 2010).

Unfortunately, research has found declines in each of these categories of creativity (see Figure 3), especially from the early 1990s to 2017 (Kim, 2011, 2017; Kim \& Pierce, 2013). 


\section{Figure 3. Changes over time in scores on the Torrance Test of Creative Thinking}

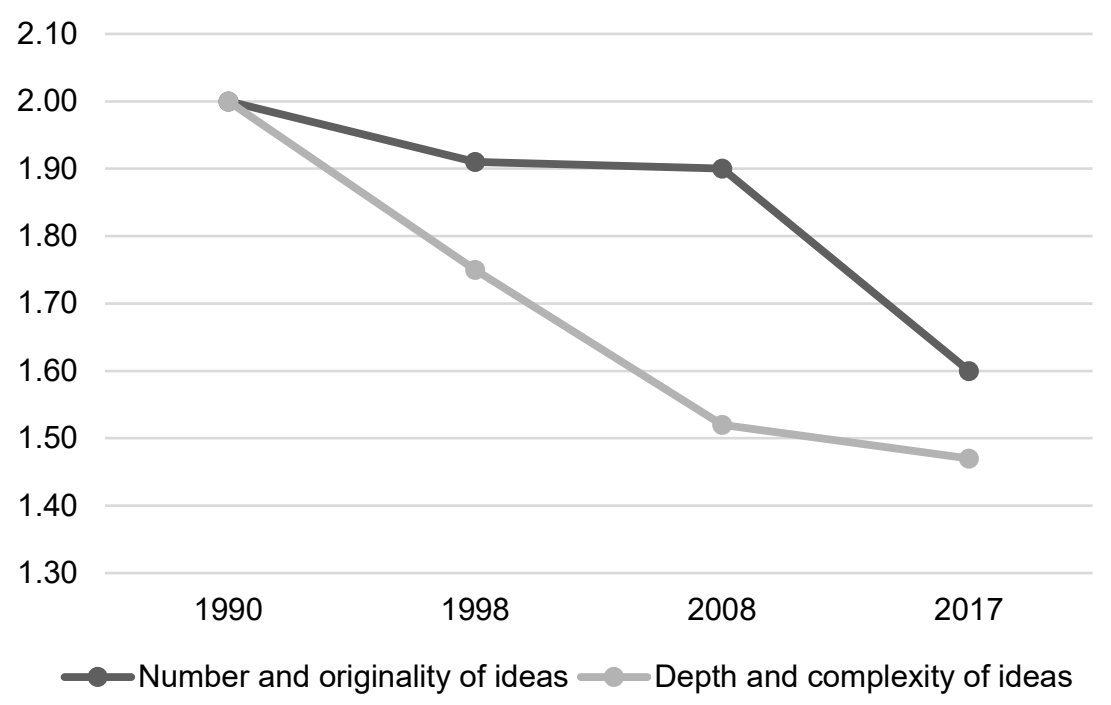

The largest declines were seen in young children (ages 5 to 8). More studies would be needed to confirm these effects on other measures, and also to better understand implications of these changes. But it is important for art museums to understand both the increased interest in visual arts creation, and the potentially increased limitations in the capacity for divergent thinking among younger generations.

\section{The hunger for connection and meaning in museum settings}

Declines in empathy, social participation, religious participation, and art museum attendance, along with rises in narcissism, individualism, and materialism suggest a crisis of meaning, especially among younger American generations. How will art museums address this existential crisis?

Considering that narcissism is rising over time, an understandable response might be to strategically cater to these trends. But in a culture of glib immediacy, authenticity will speak more loudly than hype. Connection and community will speak more deeply than shock value. Repeated, meaningful rituals will speak more personally than large one-time exhibitions. Art museums can lead the way in reversing the declines in connection over time.

There is a place for provocative new exhibits, but they may not be creating the long-term bonds or identification with art museums that will keep people coming back again and again. They may instead foster short-term self-focused engagements with visitors in which the visitor will see herself as a "consumer" who is expecting an experience that had better be good, because she could have stayed home and watched Netflix, or paid for some other interesting experience. In other words, these experiences have their place, but they may put visitors in an entitled mindset about what they can get, rather than what they can give. This may be good for short-term gains in visitor admissions, but may not help the long-term sustainability of the museum. The development of ongoing relationships with visitors can translate into future members, volunteers, and donors.

The younger generation is very savvy about their consumer power and the fact that they are being wooed by a number of declining cultural institutions. And they will respond to some of the ego-oriented strategies designed to get their attention. But what they are less accustomed to authenticity and depth. This is where the vacuum (and the opportunity) exists. 
According to a large national survey (NEA, 2015), people attend art museums for many reasons, including those related to the arts themselves (e.g. learning / experiencing new things, interest in the art). ${ }^{3}$ But a different national survey (CultureTrack, 2017) found that other top reasons that people engage are social and emotional. ${ }^{4}$ More social and emotional reasons for attending art museums are bolded in Table 1 below. Art museums have traditionally focused on the former, while neglecting the public hunger for personal connection and meaning. This may have the unintended consequence of excluding large groups of potential museum visitors who might find traditional art museum practices intimidating.

Table 1. Percent of people who said they attend art/design museums for these reasons

\begin{tabular}{|l|c|}
\hline Learning something new & $83 \%$ \\
\hline Experiencing new things & $83 \%$ \\
\hline Interest in the content & $81 \%$ \\
\hline Having fun & $78 \%$ \\
\hline Broadening my perspective or worldview & $78 \%$ \\
\hline Relaxing or feeling less stress & $76 \%$ \\
\hline Feeling inspired & $76 \%$ \\
\hline Supporting the cultural world & $71 \%$ \\
\hline Feeling transported to another place & $67 \%$ \\
\hline Feeling welcome & $66 \%$ \\
\hline Interacting with friends and/or family & $65 \%$ \\
\hline Feeling like it gives life a deeper meaning & $64 \%$ \\
\hline Connecting to my community & $54 \%$ \\
\hline Being able to go by myself & $53 \%$ \\
\hline Having grown up participating in it & $50 \%$ \\
\hline Bettering my health/well-being & $50 \%$ \\
\hline
\end{tabular}

The same survey asked people who had not attended an art museum in the past year to explain why (CultureTrack, 2017). The number one reason for not attending, listed by $46 \%$ of respondents, was because "it's not for someone like me." Another $20 \%$ mentioned other reasons related to not belonging (e.g. it's too intimidating, too many rules, I wouldn't feel welcome, or it doesn't reflect people from all backgrounds). Only 16\% listed inconvenience (hours, distance) and $10 \%$ listed cost as the main barriers to participation. This suggests that although we should not ignore convenience and cost, they are less important barriers to non-attenders than a sense of feeling unwelcome.

\section{Art museums as meaning makers}

I have several concrete suggestions about how art museums can respond to this existential crisis. All of them involve rethinking the role of art museums within communities. The three main suggestions are to: 1) Be a model of empathy, 2) Be a "palace for the people," and 3) Design evidence-based exercises that encourage empathy. I describe them in detail below. Be a model of empathy

First, art museums can play an active role in building empathy and social connection within their communities, and the first step is to be a model of empathy and warmth for visitors and those who don't currently attend.

Art museums can be negative spaces that draw sharp lines between those who belong and those who do not. There are subtle clues about who is welcome in art museums and who is not. 
Consider negative spaces in the artistic sense of the word, as paying attention to the background rather than the foreground features of an artwork. In the context of art museums, this means asking questions like:

- Imagine what the museum would look like if it was stripped bare of the artworks, but everything else went on as usual? What signals is it sending based on its structure, entrance, staff, and amenities outside of the artworks themselves?

- What are the first impressions and cues about who is welcome from the moment people step on the grounds until they walk in the main entrance?

- Is our museum easily accessible by public transit? If not, what can we do to promote this?

- How many hours would a minimum wage worker need to work to attend our museum?

- Are we open at times that are convenient for a variety of people, or are we open at times that are convenient for us?

- What options are available for people who do not speak the dominant language?

- What are some barriers in the museum for people with various disabilities? (e.g. wheelchair accessibility, accommodations for sight-impaired or hearing-impaired people)

- Do we have gender-neutral restrooms? Do we have changing tables in all restrooms? Are there nursing rooms in the building?

- Are there child-friendly exhibits (e.g. artworks placed lower; touching, running, and eating encouraged)?

- Is there a fair representation of women and people of color in top leadership positions, on the board, in the artworks, and in promotional materials?

- Are there training programs and internships that will facilitate diversity and inclusion among future staff members? Are there pathways to leadership roles for young people from underrepresented groups? (IthakaSR, 2018)

- What does the museum look like through the eyes of someone with different political beliefs from most museum staff?

- How are living artists integrated into the museum? Art museums could not exist without artists, and artists' voices should be included at all levels of the institution.

These are some initial questions, but this is more than a checklist with right or wrong answers. Instead, it should be feedback-oriented approach that involves listening to many different perspectives. I strongly recommend working with user experience designers, local artists, and community members from many different backgrounds to identify key signals about who is welcome and who is not. It would also be helpful to listen to people who may feel especially unwelcome, such as people who have never attended an art museum.

Many art museums are already incorporating such practices, and I hope that they start to share them with each other. The Museums as a Site for Social Action (MASS Action) project, led by the Minneapolis Museum of Art, is working with museum practitioners to actively engage in equity and social justice initiatives, both within the art museum and outside the museum's walls (https://www.museumaction.org). Their website includes a number of helpful free resources.

\section{Be a "palace for the people"}

This is related to the first point, but goes beyond making people feel welcome for single short visits, and instead makes them feel welcome to come, stay awhile, and then come back again and again. There is an existential vacuum in our society that art museums are uniquely poised to fill. Going deeper, more connected, more authentic, and more vulnerable is what is 
missing in many people's lives. People need a place where they are recognized and known by name, and this can't happen with one-time experiences.

In his book, Palaces for the People, sociologist Eric Klinenberg argues that these types of social connections are possible with the right social infrastructures (Klinenberg, 2018). Social infrastructures are the types of spaces in which people feel a similar sense of comfort and belonging as they might feel at home. They are what sociologist Ray Oldenburg called "third places," places that are not home or not work, but are welcoming and comfortable, free or inexpensive, have food and drink, have a variety of people, including "regulars," and are comfortable spaces to hang out, stay awhile, and come again (Oldenburg, 1989). Examples of these places include coffee shops, bars, public parks, shopping malls, and libraries. Art museums generally do not feel this way, but Klinenberg's book persuasively argues that we can address declines in social connection by mindfully making such institutions more welcoming, and this in turn will make our communities more resilient.

According to a National Endowment for the Arts survey, only $10 \%$ of people who attended a recent art event went alone; 90\% attended with relatives and friends (NEA, 2015). It's important to recognize the social nature of art museum experiences and how they can help to fulfill our needs for deep and authentic connection. These needs are not only met from connections with our family and closest friends. As I have reviewed, Americans have been retreating from public and formal spaces to their private safe cocoons. These trends represent an opportunity to make art museums (or at least parts of them) feel this way, and some scholars have already written about museums as third places (Connolly \& Bollwerk, 2016; Simon, 2010; Slater \& Jung Koo, 2010; Tate, 2012).

For example, art museums could work with other local arts groups and emerging artists to create regular interactive events. This might involve having regular open mic coffee houses with live music and poetry readings, local artists teaching techniques, maker spaces, film nights, and so on. Here it would be important to have regular and repeated times, to create a sense of ritual and so that people can transform familiar strangers into friends over time. According to a recent paper, it takes people about 50 hours of contact before they feel comfortable enough to call someone a casual friend (Hall, 2019).

The rising interest among young Americans in creating art (Figure 2) shows a hunger for being a participator, and not just a spectator. Art museums could engage people through more hands on art making activities and by offering more informal conversations with artists about how they make their art.

Another idea is to invite people who regularly work from home (like writers, freelancers, and students) to work from art museum cafes. Having free wifi, good food, free coffee refills, and many outlets would encourage this, but so would direct invitations and regular meeting times.

Art museums could also use the great halls for other purposes, such as dance performances, yoga classes, indoor walking tracks during hot or cold weather, and English as a second language conversation classes. These other uses could make people feel less intimidated by the formal museum spaces.

Finally, I would encourage the lucky art museums with beautiful outdoor spaces to pay attention to these natural settings as an important restorative space for visitors (Capaldi, Dopko, \& Zelenski, 2014; Kaplan, 1995; Packer \& Bond, 2010). Consider how to encourage people to connect with nature and enjoy quiet moments of reflection on museum grounds. 
An example of an art museum that has been trying some of these new ideas is Newfields in Indianapolis, which has been widely written about for their innovative programming such as film nights, mini golf, yoga, beer garden, and annual Winterlights on their campus (Russeth, 2019; Tugend, 2018). These programs have brought new people to the museum and its grounds, and have served as an additional source of revenue. However, Newfields' recent decision to charge admission is not without controversy, considering that it is situated within low-income communities.

Like any new ideas, it would be important to listen to community members to identify community needs and interests. And these ideas could be further developed in collaboration with art museum leaders.

\section{Design evidence-based exercises that encourage empathy}

This is also related to the first point, but it focuses on how the artworks themselves can be used to help increase empathy and social connection. In 2017, the Minneapolis Institute of Art received a \$750,000 grant from the Andrew W. Mellon Foundation to establish the world's first Center for Empathy and the Visual Arts (CEVA; Note that I serve on CEVA's advisory board.). Their goal is to collaborate with researchers, scholars, philosophers, content experts, artists, thought leaders, and colleagues at other art museums to create and disseminate a number of activities and exercises that can be used to develop empathy and related emotional skills among art museum visitors. Considering the declines in connection and rise in control, and the varieties of motivations for arts participation, this is an important goal.

Can empathy be taught? Yes, even though some people are born more empathic than others (Davis, Luce, \& Kraus, 1994; Matthews, Batson, Horn, \& Rosenman, 1981; Zahn-Waxler, Robinson, \& Emde, 1992), there are a variety of ways to help increase feelings of care, compassion, and understanding. Examples include imitating the actions or expressions of others (Barak, Engle, Katzir, \& Fisher, 1987; Stel, Van Baaren, \& Vonk, 2008), noticing similarity between self and others (Barnett, 1984), caring for vulnerable or young people or animals(C. Daniel Batson, Lishner, Cook, \& Sawyer, 2005), engaging in role taking or perspective taking (C.D. Batson, 2011), engaging in active or reflective listening (Kremer \& Dietzen, 1991), and being taught to pay attention to and recognize emotional signals in others, such as facial expressions and body language (Blanch-Hartigan, 2012).

Obviously, these exercises would need to be adapted for art museum settings, and some museums are already integrating such exercises into their practices. One example, designed by Ray Williams at Austin's Blanton Museum of Art as part of a medical student empathy-training program asks students to "Find a work of art that you might choose to share with a depressed friend. Imagine their reactions." Another suggestion is to "Find a work of art that has something to say about some aspect of love" (Williams, 2010). Students then share their responses with their peers in a safe, guided discussion.

I recommend that scientists and art museum practitioners work together to develop evidence-based empathy building activities and exercises. Museum practitioners can identify potential ideas of how to build empathy in their setting, and scientists can provide feedback on how these might engage core empathic skills and experiences. Scientists can also help to measure effectiveness of the empathy-building materials via randomized control studies (also called A/B testing) of different techniques. Minneapolis Institute of Art's Center for Empathy and Visual Art has been doing just that, and plan to share the results of their studies with broader museum audiences. 


\section{Concluding thoughts}

The practices that I recommend in this article can be seen as starting points for being a model of empathy, being a palace for the people, and designing evidence-based empathy exercises. But these starting points are incomplete without conversations and collaborations, among and between art museum practitioners and their stakeholders.

Art museums need to be mindful of their role as postmodern temples of meaning. They are guardians who safeguard sacred memories, spaces, and dreams of people from all times and places. It's time for art museums to see themselves as more than just buildings and collections. It's time to give more to your visitors, but also to ask more of them. Engage them in long-term relationships by creating warm, safe, inviting spaces in which they can address their needs for meaning, connection, and authenticity. In doing so, art museums can be weavers of the invisible strings that connect us all. 


\section{References}

Barak, A., Engle, C., Katzir, L., \& Fisher, W. A. (1987). Increasing the level of empathic understanding by means of a game. Simulation \& Gaming, 18(4), 458-470.

Barnett, M. A. (1984). Similarity of experience and empathy in preschoolers. The Journal of genetic psychology, 145(2), 241-250.

Batson, C. D. (2011). Altruism in humans: Oxford University Press.

Batson, C. D., Lishner, D. A., Cook, J., \& Sawyer, S. (2005). Similarity and nurturance: Two possible sources of empathy for strangers. Basic and Applied Social Psychology, 27(1), $15-25$.

Blanch-Hartigan, D. (2012). An effective training to increase accurate recognition of patient emotion cues. Patient education and counseling, 89(2), 274-280.

Bureau, U. S. C. (2017a). Average Number of Own Children Under 18 Per Family, By Type of Family: 1955 to Present, Historical Families Tables Table FM-3. https://www.census.gov/data/tables/timeseries/demo/families/families.html.

Bureau, U. S. C. (2017b). Families by Presence of Own Children Under 18: 1950 to Present, Historical Families Tables Table FM-1. https://www.census.gov/data/tables/timeseries/demo/families/families.html.

Bureau, U. S. C. (2017c). Living Arrangements of Adults 18 and Over, 1967 to Present, Historical Living Arrangements

of Adults Table AD-3. https://www2.census.gov/programs-surveys/demo/tables/families/timeseries/adults/ad3.xlsx.

Capaldi, C. A., Dopko, R. L., \& Zelenski, J. M. (2014). The relationship between nature connectedness and happiness: a meta-analysis. Frontiers in psychology, 5, 976.

Carmichael, C. L., Reis, H. T., \& Duberstein, P. R. (2015). In your 20s it's quantity, in your 30s it's quality: The prognostic value of social activity across 30 years of adulthood.

Psychology and Aging, 30(1), 95.

Chopik, W., Joshi, D., \& Konrath, S. (2014). Historical changes in American self-interest: State of the Union addresses 1790 to 2012. . Personality and Individual Differences, 66, 128133.

Connolly, R. P., \& Bollwerk, E. A. (2016). Positioning Your Museum as a Critical Community Asset: A Practical Guide: Rowman \& Littlefield.

Control, C. f. D. (2016). Data Brief 241: Increase in Suicide in the United States, 1999-2014. https://www.cdc.gov/nchs/products/databriefs/db241.htm.

CultureTrack. (2017). La Placa Cohen. https://culturetrack.com.

Curran, T., \& Hill, A. P. (2019). Perfectionism is increasing over time: A meta-analysis of birth cohort differences from 1989 to 2016. Psychological Bulletin, 145(4), 410.

Davis, M., Luce, C., \& Kraus, S. (1994). The heritability of characteristics associated with dispositional empathy. Journal of Personality, 62(3), 369-391.

DeWall, C., Pond, R., Campbell, W. K., \& Twenge, J. (2011). Tuning in to psychological change: linguistic markers of psychological traits and emotions over time in popular U.S. song lyrics. Psychology of Aesthetics, Creativity, and the Arts, in press.

Dietz, N., \& Grimm, R. (2016). Doing good by the young and old: Forty years of American volunteering. Nonprofit Quarterly, November 17.

DiMaggio, P., \& Mukhtar, T. (2004). Arts participation as cultural capital in the United States, 1982-2002: Signs of decline? Poetics, 32(2), 169-194. 
Eagan, K., Stolzenberg, E., Ramirez, J., Aragon, M., Suchard, M., \& Rios-Aguilar, C. (2016). The American Freshman: Fifty-Year trends, 1966-2015. Los Angeles: Higher Education Research Institute, UCLA.

Gentile, B., Twenge, J. M., \& Campbell, W. K. (2010). Birth Cohort Differences in Self-Esteem, 1988-2008: A Cross-Temporal Meta-Analysis. Review of General Psychology, 14(3), 261-268. doi:10.1037/a0019919

Greenfield, P. M. (2013). The changing psychology of culture from 1800 through 2000. Psychological Science, 24(9), 1722-1731.

Grossmann, I., \& Varnum, M. E. (2015). Social structure, infectious diseases, disasters, secularism, and cultural change in America. Psychological Science, 26(3), 311-324.

GSS. (2016a). combination of two variables (visart, visitart) and weighted (wtssall). General Social Survey.

GSS. (2016b). Variable “makeart,” weighted by wtssall. General Social Survey.

GSS. (2016c). Whether religious or not by year, weighted by wtssall. General Social Survey.

Hall, J. A. (2019). How many hours does it take to make a friend? Journal of Social and Personal Relationships, 36(4), 1278-1296.

Hampton, K. N. (2016). Why is helping behavior declining in the United States but not in Canada?: Ethnic diversity, new technologies, and other explanations. City \& Community, 15(4), 380-399.

Hochreich, D. J., \& Rotter, J. B. (1970). Have college students become less trusting? Journal of Personality and Social Psychology, 15(3), 211-214.

Holt-Lunstad, J., Smith, T. B., Baker, M., Harris, T., \& Stephenson, D. (2015). Loneliness and social isolation as risk factors for mortality: a meta-analytic review. Perspectives on Psychological Science, 10(2), 227-237.

Holt-Lunstad, J., Smith, T. B., \& Layton, J. B. (2010). Social Relationships and Mortality Risk: A Meta-analytic Review. PLoS Med, 7(7), e1000316. doi:10.1371/journal.pmed.1000316

IthakaSR. (2018). Case Studies in Museum Diversity. http://www.sr. ithaka.org/landing/casestudies-in-museum-diversity.

Kaplan, S. (1995). The restorative benefits of nature: Toward an integrative framework. Journal of Environmental Psychology, 15(3), 169-182.

Kasser, T., \& Ryan, R. M. (1996). Further examining the American dream: Differential correlates of intrinsic and extrinsic goals. Personality and Social Psychology Bulletin, 22(3), 280-287.

Kesebir, P., \& Kesebir, S. (2012). The cultural salience of moral character and virtue declined in twentieth century America. The Journal of Positive Psychology, 7(6), 471-480.

Kim, K. H. (2011). The creativity crisis: The decrease in creative thinking scores on the Torrance Tests of Creative Thinking. Creativity Research Journal, 23(4), 285-295.

Kim, K. H. (2017). Creativity Crisis Update: How high stakes testing stifles innovation. http://www.creativitypost.com/education/the 2017 creativity_crisis_update_how_high_s takes testing has stifled innov.

Kim, K. H., \& Pierce, R. A. (2013). Decrease in Creativity. In Encyclopedia of Creativity, Invention, Innovation and Entrepreneurship (pp. 519-523): Springer.

Klinenberg, E. (2018). Palaces for the people: How social infrastructure can help fight inequality, polarization, and the decline of civic life. New York, NY: Crown Publishing Group. 
Konrath, S., \& Anderson, P. (2011). A century of self-esteem. In S. De Wals \& K. Meszaros (Eds.), Handbook on Psychology of Self-Esteem: Nova Science Publishers.

Konrath, S., \& Bonadonna, J. P. (2014). Physiological and health-related correlates of the narcissistic personality. In A. Besser (Ed.), Psychology of Narcissism. Hauppauge, New York: Nova Science Publishers, Inc.

Konrath, S., Meier, B. P., \& Bushman, B. J. (2014). Development and validation of the Single Item Narcissism Scale (SINS). PLoS ONE, 9(8), e103469.

Konrath, S., O'Brien, E. H., \& Hsing, C. (2011). Changes in Dispositional Empathy in American College Students Over Time: A Meta-Analysis. Personality and Social Psychology Review, 15(2), 180-198. doi:10.1177/1088868310377395

Kremer, J. F., \& Dietzen, L. L. (1991). Two approaches to teaching accurate empathy to undergraduates: Teacher-intensive and self-directed. Journal of College Student Development.

Levine, R. V., Reysen, S., \& Ganz, E. (2008). The kindness of strangers revisited: A comparison of 24 US cities. Social Indicators Research, 85(3), 461-481.

Malahy, L. W., Rubinlicht, M. A., \& Kaiser, C. R. (2009). Justifying inequality: A crosstemporal investigation of US income disparities and just-world beliefs from 1973 to 2006. Social Justice Research, 22(4), 369-383.

Matthews, K. A., Batson, C. D., Horn, J., \& Rosenman, R. H. (1981). Principles in his nature which interest him in the fortune of others: The heritability of empathic concern for others. Journal of Personality, 49(3), 237-247.

McPherson, M., Smith-Lovin, L., \& Brashears, M. E. (2006). Social isolation in America: Changes in core discussion networks over two decades. American Sociological Review, 71(3), 353-375.

Mojtabai, R., \& Olfson, M. (2014). National trends in long-term use of antidepressant medications: results from the US National Health and Nutrition Examination Survey. The Journal of Clinical Psychiatry, 75(2), 169-177.

NEA. (2013). How A Nation Engages With Art. National Endowment for the Arts, https://www.arts.gov/sites/default/files/highlights-from-2012-sppa-revised-oct-2015.pdf.

NEA. (2015). When going gets tough: Barriers and motivations affecting arts attendance. National Endowment for the Arts, https://www.arts.gov/sites/default/files/when-goinggets-tough-revised2.pdf, 44.

Oldenburg, R. (1989). The Great Good Place: Cafes, Coffee Shops, Community Centers, Beauty Parlors, General Stores, Bars, Hangouts, and How They Get You Through the Day. New York, NY: Paragon House.

Olfson, M., Blanco, C., Wang, S., Laje, G., \& Correll, C. U. (2014). National trends in the mental health care of children, adolescents, and adults by office-based physicians. JAMA psychiatry, 71(1), 81-90.

Packer, J., \& Bond, N. (2010). Museums as restorative environments. Curator: The Museum Journal, 53(4), 421-436.

Piketty, T. (2014). Capital in the twenty-first century. Cambridge Massachusetts: The Belknap Press of Harvard University Press.

Rahn, W. M., \& Transue, J. E. (1998). Social trust and value change: The decline of social capital in American youth, 1976-1995. Political Psychology, 19(3), 545-565. 
Rooney, P. M., Wang, X., \& Ottoni-Wilhelm, M. (2018). Generational Succession in American Giving: Donors Down, Dollars Per Donor Holding Steady But Signs That It Is Starting to Slip. Nonprofit and Voluntary Sector Quarterly, 0899764018770281.

Roose, H., \& Daenekindt, S. (2015). Trends in cultural participation. International Encyclopedia of the Social and Behavioral Sciences, 2nd Ed., Volume 5, 441-452.

Runco, M., Millar, G., Acar, S., \& Cramond, B. (2010). Torrance tests of creative thinking as predictors of personal and public achievement: A fifty-year follow-up. . Creativity Research Journal, 22(4), 361-368.

Russeth, A. (2019). The Ringmaster: Is Charles Venable Democratizing a Great Art Museum in Indianapolis — or Destroying It? ArtNews, http://www.artnews.com/2019/07/09/charlesvenable-newfields-indianapolis-museum/.

Ryan, R. M., Huta, V., \& Deci, E. L. (2008). Living well: A self-determination theory perspective on eudaimonia. Journal of Happiness Studies, 9(1), 139-170.

Santos, H. C., Varnum, M. E., \& Grossmann, I. (2017). Global increases in individualism. Psychological Science, 28(9), 1228-1239.

Schwadel, P., \& Stout, M. (2012). Age, period and cohort effects on social capital. Social Forces, 91(1), 233-252.

Seth, P., Rudd, R. A., Noonan, R. K., \& Haegerich, T. M. (2018). Quantifying the epidemic of prescription opioid overdose deaths. In: American Public Health Association.

Simon, N. (2010). The participatory museum: Museum 2.0.

Slater, A., \& Jung Koo, H. (2010). A new type of "Third Place"? Journal of place management and development, 3(2), 99-112.

Spring, K., Grimm, R., \& Dietz, N. (2008). Community Service and Service-Learning in America's Schools. Corporation for National and Community service, Office of Research and Policy Development(Washington, DC).

Stallings, S. N., \& Mauldin, B. (2016). Public Engagement in the Arts: A review of recent literature. . In: Ford Theatre Foundation, and Los Angeles County Arts Commission.

Stel, M., Van Baaren, R. B., \& Vonk, R. (2008). Effects of mimicking: Acting prosocially by being emotionally moved. European Journal of Social Psychology, 38(6), 965-976.

Tate, N. B. (2012). Museums as third places or what? Accessing the social without reservations. Museums \& Social Issues, 7(2), 269-283.

Tavernise, S. (2016). U.S. Suicide rate surges to a 30 year high. New York Times.

Tugend, A. (2018). To Reach New Audiences, Museums Are Redefining What They Offer. The New York Times, https://www.nytimes.com/2018/03/12/arts/to-reach-new-audiencesmuseums-are-redefining-what-they-offer.html.

Twenge, J. (2015). Time period and birth cohort differences in depressive symptoms in the US, 1982-2013. Social Indicators Research, 121(2), 437-454.

Twenge, J., Abebe, E. M., \& Campbell, W. K. (2010). Fitting in or standing Out: Trends in American parents' choices for children's names, 1880-2007. Social Psychological and Personality Science, 1(1), 19-25.

Twenge, J., Campbell, S. M., Hoffman, B. J., \& Lance, C. E. (2010). Generational differences in work values: Leisure and extrinsic values increasing, social and intrinsic values decreasing. Journal of Management, 36(5), 1117-1142.

Twenge, J., \& Campbell, W. K. (2001). Age and Birth Cohort Differences in Self-Esteem: A Cross-Temporal Meta-Analysis. Personality and Social Psychology Review, 5(4), 321344. doi:10.1207/s15327957pspr0504_3 
Twenge, J., Campbell, W. K., \& Carter, N. T. (2014). Declines in trust in others and confidence in institutions among American adults and late adolescents, 1972-2012. Psychological Science, 25(10), 1914-1923.

Twenge, J., Campbell, W. K., \& Freeman, E. C. (2012). Generational differences in young adults' life goals, concern for others, and civic orientation, 1966-2009. Journal of Personality and Social Psychology, 102(5), 1045.

Twenge, J., Campbell, W. K., \& Gentile, B. (2012). Increases in individualistic words and phrases in American books, 1960-2008. PLoS ONE, 7(7), e40181.

Twenge, J., Campbell, W. K., \& Gentile, B. (2013). Changes in pronoun use in American books and the rise of individualism, 1960-2008. Journal of Cross-Cultural Psychology, 44(3), 406-415.

Twenge, J., \& Foster, J. (2010). Birth Cohort Increases in Narcissistic Personality Traits Among American College Students, 1982-2009. Social Psychological and Personality Science, 1(1), 99-106. doi:10.1177/1948550609355719

Twenge, J., Gentile, B., DeWall, C. N., Ma, D., Lacefield, K., \& Schurtz, D. R. (2010). Birth cohort increases in psychopathology among young Americans, 1938-2007: A crosstemporal meta-analysis of the MMPI. Clinical Psychology Review, 30(2), 145-154.

Twenge, J., \& Kasser, T. (2013). Generational changes in materialism and work centrality, 19762007: Associations with temporal changes in societal insecurity and materialistic role modeling. Personality and Social Psychology Bulletin, 39(7), 883-897.

Twenge, J., Konrath, S., Foster, J., Campbell, W. K., \& Bushman, B. J. (2008). Egos inflating over time: a cross-temporal meta-analysis of the Narcissistic Personality Inventory. Journal of Personality, 76(4), 875-902; discussion 903-918. doi:JOPY507 [pii] 10.1111/j.1467-6494.2008.00507.x

Twenge, J., VanLandingham, H., \& Keith Campbell, W. (2017). The seven words you can never say on television: Increases in the use of swear words in American books, 1950-2008. Sage Open, 7(3), 2158244017723689.

Vonnegut, K. (2005). A man without a country. New York, NY: Random House.

Watson, P., \& Morris, R. J. (1991). Narcissism, empathy and social desirability. Personality and Individual Differences, 12(6), 575-579.

Watts, D. J. (2004). Six degrees: The science of a connected age: WW Norton \& Company.

Williams, R. (2010). Honoring the personal response: A strategy for serving the public hunger for connection. Journal of Museum Education, 35(1), 93-102.

Wilson, R. (2017). More Americans are living alone after recession. The Hill, https://thehill.com/homenews/state-watch/355122-more-americans-are-living-aloneafter-recession.

Zahn-Waxler, C., Robinson, J. L., \& Emde, R. N. (1992). The development of empathy in twins. Developmental Psychology, 28(6), 1038. 


\section{Endnotes}

${ }^{1}$ This survey also found a decline in art museum attendance between 2011 (58\% attended at least once) and 2017 (53\%).

2 There is also a verbal version of the test that asks people to think of as many uses as they can for objects such as cans or books.

${ }^{3}$ As a scientist, I feel compelled to note that people in scientific occupations are $2.5 X$ more likely to attend visual or performing arts events. The survey does not say why, but I would guess that intellectual curiosity is a big driver. The arts are sciences are more complementary than people might otherwise assume.

${ }^{4}$ NEA (2015) also conducted a recent survey on motivations for attending visual art exhibit, however, they asked fewer questions (see below for results). Since La Placa included these questions, plus more social and emotional ones, I focus on this survey for this paper.

\begin{tabular}{|l|c|l|c|}
\hline $\begin{array}{l}\text { NEA, Motivation for attending visual art } \\
\text { exhibit }\end{array}$ & Percent & $\begin{array}{l}\text { NEA, Barriers for not attending } \\
\text { visual art exhibit }\end{array}$ & Percent \\
\hline Learn new things & $88 \%$ & Lack of time, or work & $55 \%$ \\
\hline Experience high quality art & $73 \%$ & Too difficult to get there, or disability & $43 \%$ \\
\hline Visit the location or venue & $72 \%$ & Cost too much & $27 \%$ \\
\hline Socialize with friends or family & $68 \%$ & Couldn't find anyone to go with & $22 \%$ \\
\hline Support community events & $56 \%$ & Program or event not of interest & $5.9 \%$ \\
\hline Benefit from low cost or free admission & $42 \%$ & Didn't want to visit that location & $5.6 \%$ \\
\hline Celebrate cultural heritage & $27 \%$ & & \\
\hline See specific artist or performer & $6 \%$ & & \\
\hline
\end{tabular}

